\title{
Impact of Temperature on Seed Dormancy
}

\author{
Robert L. Geneve ${ }^{1}$ \\ Department of Horticulture, University of Kentucky, Lexington, KY 40546
}

Additional index words. germination, scarification, stratification, embryo, after-ripening, thermodormancy

Seed dormancy is an ecological adaptation that allows seasonal timing of germination for seeds in a population. Several environmental stimuli can trigger dormancy release, the most important being seed moisture content, light and temperature. Of these, temperature is arguably the most important. The objective of this brief review is to consider the various ways temperature impacts seed dormancy release. It will cover general aspects of seed dormancy, temperature effects on primary dormancy and considerations for conducting and interpreting seed dormancy research.

Propagators of cultivated plants have long recognized that germination-delaying mechanisms exist in seeds. The first recorded discussion of seed dormancy was written by Theophrastus in $\approx 300$ B.C. (Evenari, 1981). He recognized that germination of most seeds declined during storage (seed deterioration), while germination in some seeds increased (dormancy release).

One problem with discussing seed dormancy is that there is no single recognized terminology to describe the many different types of seed dormancy. Crocker (1916) described seven types of dormancy based on treatments used to overcome them. Subsequently, Nikolaeva (1977) defined dormancy based primarily upon physiological controls. More recently, Lang (1987) proposed the terms eco-, para-, and endo-dormancy to simplify terminology. This system is currently utilized in American Society for Horticultural Science journals. However, this terminology is not sufficient to adequately describe all the types of dormancy found in seeds. Baskin and Baskin (1998) have developed the most complete set of terms to describe seed dormancy. They have extended the dormancy classifications of Nikolaeva to include additional specialty types. In this review, I will use a system based on the work of Nikolaeva, as modified by Baskin and Baskin (Hartmann et al., 2002). It is a classification system that I feel fits both the ecological and horticultural aspects of seed dormancy and is accepted by most of the scientists working in the field of seed biology (Table 1).

\section{SEED DORMANCY CATEGORIES}

Major categories include primary and secondary seed dormancy. Primary dormancy is a condition that exists in the seed as it is shed from the plant. In contrast, secondary dormancy occurs in seeds that were previously non-dormant, but have become dormant because the environment was unfavorable for germination. Primary dormancy, includes exogenous dor-

Received for publication 4 Apr. 2002. Accepted for publication 4 Sept. 2002. Univ. of Kentucky Experiment Station publication \#02-11-27.

${ }^{1}$ E-mail address: rgeneve@uky.edu mancy, endogenous dormancy, and combination dormancy. Secondary dormancy includes thermodormancy and conditional dormancy.

These types of dormancy and the requirements to overcome them are listed in Table 1. Detailed descriptions of these categories can be found elsewhere (Baskin and Baskin, 1998; Geneve, 1998; Hartmann et al., 2002). In this review, I will limit each category to a brief description and emphasize dormancy conditions that are affected by temperature.

\section{Primary exogenous dormancy}

In exogenous dormancy, the tissues enclosing the embryo impact germination by either inhibiting water uptake, modifying gas $\left(\mathrm{O}_{2}\right)$ exchange, or possibly contain germination inhibitors (Bewley and Black, 1994).

Seeds of species with exogenous physical dormancy fail to imbibe water because of properties of the seed coverings. This form of seed dormancy only occurs in 15 plant families (Baskin et al., 2000). Of these, most of the species displaying physical dormancy are found in the Malvaceae and Fabaceae. The anatomical structures preventing water uptake can be the seedcoat (testa) or endocarp (Baskin et al., 2000). In most species, there are elongated palisade cells in the outer layer of the seedcoat (exotesta) that prevent imbibition. Mechanical abrasion or chemical degradation of the seed coverings and submersion of the seed in hot water are the most common horticultural practices to induce seeds with physical dormancy to imbibe water. Collectively, these treatments are termed scarification. However, in nature, it appears that temperature is the major factor determining water uptake in seeds with physical dormancy.

Temperature impacts dormancy release for seeds with exogenous physical dormancy by affecting the seed coverings. For instance, some seeds require high temperature or daily fluctuations $\left(>15^{\circ} \mathrm{C}\right.$ change $)$ in temperature to allow imbibition. This requirement is postulated as a way for seeds to detect whether they are in open or protected areas (Baskin and Baskin, 1998). A higher daily temperature extreme, as well as a greater day/night fluctuation would occur in an open area, indicating less competition from other plants after germination. The coverings of seeds with physical dormancy may also be cracked by temperature fluctuations, alternate freezing and thawing and in some species by fire.

For many seeds with physical dormancy, a specialized location on the seed coverings can act as an "environmental sensor." In the Fabaceae, it is usually the lens (strophiole) (Manning and van Staden, 1987; Morrison et al., 1998); and in the Malvaceae, it is the chalazal plug (Egley, 1989). These structures are disrupted by temperature and become the site of water entry into the seed. For example, Quinlivan (1968) demonstrated that seeds of Lupinus varius L. became permeable to water at the lens after exposure to fluctuating temperature (i.e., $65^{\circ} \mathrm{C}$ day temperatures with night temperatures down to $25^{\circ} \mathrm{C}$ ).

\section{Primary endogenous dormancy}

The second major category of primary seed dormancy is endogenous seed dormancy. Seeds with endogenous dormancy fail to germinate because of factors associated with the embryo. There are two types of endogenous dormancy - morphological and physiological.

Morphological dormancy. Seeds with morphological dormancy have an embryo that is not fully developed at the time of seed dissemination. Seeds where the embryo fills less than half of the seed are considered to have morphological dormancy (Baskin and Baskin, 1998). Enlargement of the embryo occurs after the seeds have imbibed water, but usually before germination begins. The process of embryo enlargement is influenced by temperature. Atwater (1980) distinguished three types of morphological dormancy based on the embryo type found in herbaceous flower crops. These are rudimentary, linear, and undifferentiated embryo types.

Rudimentary embryos are little more than a proembryo embedded in a massive endosperm. These are found in seeds of various families, such as the Ranunculaceae, Papaveraceae, and Araliaceae. Germination-inhibiting chemicals may occur in the endosperm and become active at high temperatures. Methods for inducing germination include: (a) exposure to temperatures of $15{ }^{\circ} \mathrm{C}$ or below; (b) exposure to alternating temperatures; and (c) treatment with chemicals such as potassium nitrate or gibberellic acid.

Seeds with linear embryos are torpedoshaped and up to one-half the size of the seed. Important families and species in this category include the Apiaceae, Ericaceae, Primulaceae, and Gentianaceae. Conditions such as semipermeability of the inner seedcoats and internal germination inhibitors may be involved. Temperature $>20{ }^{\circ} \mathrm{C}$ favors germination, as does treatment with gibberellic acid.

Some tropical species have seeds with small embryos that require an extended period at warm temperatures for germination to take place. For example, seeds of some palm species require 1 to 3 months at high temperatures $\left(\approx 35^{\circ} \mathrm{C}\right)$ to complete germination (Nagao et al., 1980). Other examples include Actinidia sp. and Annona squamosa L. whose seeds require 2 or 3 months at warm temperatures, respectively, to complete germination (Nikolaeva, 1977). 
Table 1. Seed dormancy categories (Hartmann et al., 2002).

\begin{tabular}{|c|c|c|c|}
\hline Dormancy types & Causes of dormancy & Conditions to break dormancy & Representative genera \\
\hline \multicolumn{4}{|l|}{ 1. Primary dormancy } \\
\hline a. Exogenous dormancy & Imposed by factors outside the embryo & & \\
\hline Physical & Impermeable seedcoat & Scarification & $\begin{array}{l}\text { Baptisia, Convolvulus, } \\
\text { Gleditsia, Lupinus }\end{array}$ \\
\hline Chemical & Inhibitors in seed coverings & $\begin{array}{l}\text { Removal of seed coverings (fruits) } \\
\text { Leaching seeds }\end{array}$ & Beta, Iris \\
\hline b. Endogenous dormancy & Imposed by factors in the embryo & & \\
\hline Morphological & $\begin{array}{l}\text { The embryo is not fully developed } \\
\text { at the time theseed sheds from the plant }\end{array}$ & Warm or cold stratification & \\
\hline Rudimentary & Small undifferentiated embryo & Cold stratification and potassium nitrate & Anemone, Ranunculus \\
\hline Linear & Small differentiated embryo $<1 / 2$ size of seed & Warm stratification and gibberellic acid & $\begin{array}{l}\text { Daucus, Cyclamen, } \\
\text { Viburnum }\end{array}$ \\
\hline Physiological & Factors within embryo inhibits germination & & \\
\hline \multirow[t]{3}{*}{ Nondeep } & Positively photodormant (requires light) & Red light & Lactuca, Primula \\
\hline & Negatively photodormant (inhibited by light) & Darkness & Cyclamen, Nigella \\
\hline & After-ripening & Short period of dry storage & Cucumis, Impatiens \\
\hline Intermediate & $\begin{array}{l}\text { Embryo germinates if separated from the seedcoat } \\
\text { Often responds to gibberellic acid }\end{array}$ & $\begin{array}{l}\text { Moderate periods (up to } 8 \text { weeks) of } \\
\text { cold stratification }\end{array}$ & Aconitum, Cornus, Pinus \\
\hline Deep & $\begin{array}{l}\text { Embryo does not germinate when removed from } \\
\text { seedcoat or will form a physiological dwarf }\end{array}$ & $\begin{array}{l}\text { Long periods ( }>8 \text { weeks) of cold } \\
\text { stratification }\end{array}$ & $\begin{array}{l}\text { Dictamnus, Euonymus, } \\
\text { Prunus, Rhodotypos }\end{array}$ \\
\hline c. Combinational & $\begin{array}{l}\text { Combinations of different dormancy } \\
\text { conditions that must be satisfied sequentially }\end{array}$ & & \\
\hline Morphophysiological & $\begin{array}{l}\text { Combination of underdeveloped or rudimentary } \\
\text { embryo and physiological dormancy }\end{array}$ & Cycles of warm and cold stratification & $\begin{array}{l}\text { Asimina, Helleborus, Ilex, } \\
\text { Magnolia, Mertensia }\end{array}$ \\
\hline Epicotyl & $\begin{array}{l}\text { Radicle begins growth when temperature } \\
\text { and water permit, but epicotyl is dormant }\end{array}$ & Warm followed by cold stratification & Asarum, Paeonia \\
\hline $\begin{array}{l}\text { Epicotyl and radicle } \\
\text { (double dormancy) }\end{array}$ & $\begin{array}{l}\text { Radicle and epicotyl require chilling stratification, } \\
\text { but radicle is released during first year and then }\end{array}$ & $\begin{array}{l}\text { Cold stratification followed by warm } \\
\text { followed by a second cold stratification }\end{array}$ & Convallaria, Trillium \\
\hline Exo-endodormancy & $\begin{array}{l}\text { Combinations of exogenous and endogenous } \\
\text { dormancy conditions. Example: physical (hard } \\
\text { seedcoat) plus intermediate physiological } \\
\text { dormancy }\end{array}$ & $\begin{array}{l}\text { Sequential combinations of dormancy } \\
\text { releasing treatments. Example: } \\
\text { scarification followed by cold } \\
\text { stratification }\end{array}$ & Cercis, Tilia \\
\hline \multicolumn{4}{|l|}{ 2. Secondary dormancy } \\
\hline a. Thermodormancy & $\begin{array}{l}\text { After primary dormancy is relieved, high } \\
\text { temperature induces dormancy }\end{array}$ & Growth regulators or cold stratification & Apium, Lactuca, Viola \\
\hline b. Conditional dormancy & $\begin{array}{l}\text { Change in ability to germinate related to time } \\
\text { of the year }\end{array}$ & Chilling stratification & $\begin{array}{l}\text { Many species with endo- } \\
\text { genous dormancy display } \\
\text { conditional dormancy }\end{array}$ \\
\hline
\end{tabular}

Orchid seeds have undifferentiated embryos when shed from the mother plant. They are not considered dormant in the same sense as others in this category because they lack substantial seed storage materials.

Physiological dormancy. The second type of endogenous dormancy is physiological dormancy. This type of dormancy involves physiological changes within the embryo allow the radicle to escape the restraint of the seed coverings. Physiological dormancy includes nondeep, intermediate, and deep categories.

Endogenous, nondeep, physiological dormancy is the most common form of seed dormancy (Baskin and Baskin, 1998). This type of dormancy can be broken by light or darkness (photodormancy), short periods of chilling stratification, or "after-ripening" (dry storage).

Seeds from species with endogenous, nondeep, physiological dormancy (especially small seeded species) often require light or darkness for germination. Light sensitivity in seeds is a phytochrome response (Casal and Sánchez, 1998). For some seeds, there is a distinct light $\times$ temperature interaction regarding dormancy and germination. A light requirement can be offset by cool temperatures and sometimes, by alternating temperatures. Seeds of some cultivars of lettuce generally require light to germinate; however, they can germinate in darkness at temperatures below 23 ${ }^{\circ} \mathrm{C}$ (Hadnagy, 1972). For years, birch (Betula sp.) seeds were thought to require moist chilling to permit germination. However, nonchilled seeds will germinate in light (Vanhatalo et al., 1996).

Freshly harvested seeds of some herbaceous plants display endogenous, nondeep physiological dormancy (Association of Official Seed Analysts, 1993; Atwater, 1980; Baskin and Baskin, 1998). This type of dormancy is often transitory and disappears during dry storage (after-ripening). For most cultivated cereals, grasses, vegetables, and flower crops, nondeep physiological dormancy may last for 1 to 6 months and disappears with dry storage during normal handling procedures (Geneve, 1998).

Temperature affects the time required to after-ripen seeds. For example, cultivated cucumber (Cucumis sativus var. sativus L.) has been selected over many years of cultivation for a short dormancy period. Freshly harvested seeds lose dormancy in dry storage at room temperature after several weeks ( 15 to $30 \mathrm{~d}$ ). The hardwickii cucumber [Cucumis sativus var. hardwickii (Royle) Alef.] is considered a wild progenitor species of the cultivated cucumber and seeds can remain dormant for 60 to 270 d (Weston et al., 1992). Dormancy release occurred much earlier in hardwickii seeds held in dry storage at warmer temperatures $\left(180 \mathrm{~d}\right.$ at $17{ }^{\circ} \mathrm{C}$ compared to only $75 \mathrm{~d}$ at $\left.37^{\circ} \mathrm{C}\right)$. Roberts $(1965)$ showed that there was a negative linear relationship between after-ripening time and temperature that was consistent within a species. He showed that time on a log scale to reach $50 \%$ germination was linear with temperature.

Moist chilling stratification can relieve dormancy in species with nondeep, intermediate, or deep physiological dormancy (Fig. 1). It is often difficult to differentiate between seeds that display nondeep vs. intermediate physiological dormancy. In general, seeds with nondeep dormancy require only short periods (days or up to several months) of chilling stratification to relieve dormancy. Seeds with intermediate physiological dormancy usually require at least 2 months of chilling or gibberellin application can substitute for chilling. Embryos isolated from their seed coverings in nondeep or intermediate physiologically dormant seeds will germinate promptly and produce normal seedlings. In contrast, seeds with deep physiological dormancy require long periods ( $>3$ months) of chilling stratification to relieve dormancy and generally do not respond to exogenous gibberellin application. Embryos isolated from these seeds either will not germinate or will grow into abnormal seedlings with a dwarf phenotype, termed physiological dwarfs (Flemion and Waterbury, 1945).

In most cases, seeds with endogenous physiological dormancy respond in a similar manner with regard to stratification temperature. A temperature near $4{ }^{\circ} \mathrm{C}$ has maximum effect, while below freezing temperatures or 


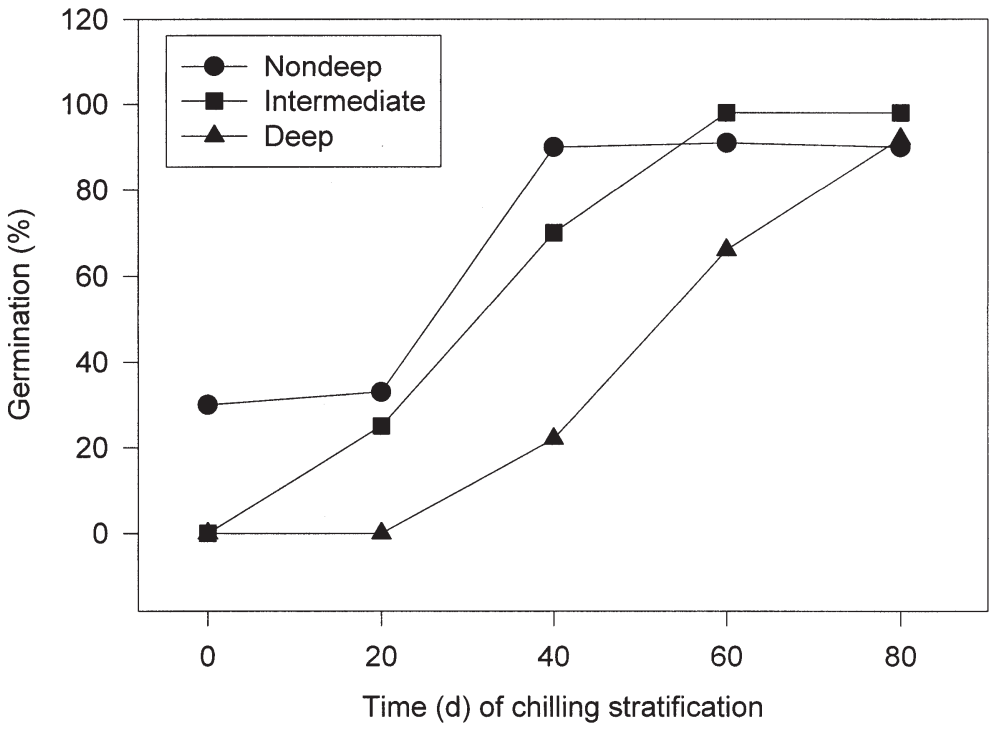

Fig. 1. Hypothetical germination curves for seeds with differing degrees of nondeep, intermediate, and deep physiological dormancy chilled for various times before being transferred to optimal germination conditions.

temperatures above 14 to $16^{\circ} \mathrm{C}$ are generally not effective for relieving dormancy (Seeley, 1997). This observation has led to the concept of stratification degree hours for predicting the time required to relieve dormancy (Seeley and Damavandy, 1985). One hour at optimum stratification temperature $\left(4^{\circ} \mathrm{C}\right)$ is equal to one "stratification degree hour." Partial stratification degree hour values are assigned to warmer or cooler temperatures, but temperatures below freezing and above $16^{\circ} \mathrm{C}$ have no effect toward dormancy release. In addition, time above 16 ${ }^{\circ} \mathrm{C}$ can negate previous chilling.

Some species have seed lots where some seeds may not require stratification to germinate but the rate of seedling emergence is improved for all seeds by brief exposure to chilling temperatures. This phenomenon has been referred to as a facultative form of physiological dormancy (Geneve, 1998). Genera in this group include Antirrhinum, Eustoma, and Impatiens (Ecker et al., 1994; Montero et al., 1990; Simmonds, 1980) and various conifers (Jones and Gosling, 1994). For example, in purple coneflower [Echinacea purpurea (L.) Moench.] germination percentage and rate of emergence were improved in five of six seed lots by a $10-\mathrm{d}$ treatment of either 5 or $10{ }^{\circ} \mathrm{C}$ (Wartidininghsih and Geneve, 1994).

\section{Primary combinational dormancy}

Combinational dormancy combines two or more kinds of dormancy, such as morphophysiological dormancy, where there is an underdeveloped embryo and physiological dormancy (Ilex) or exo-endodormancy that combines seedcoat dormancy and endogenous physiological dormancy (Cercis canadensis L.). To induce germination, all blocking conditions must be eliminated in proper sequence.

Morphophysiological dormancy. The most common form of combinational dormancy is morphophysiological dormancy. Currently, eight different types of morphophysiologi- cal dormancy are recognized (Baskin and Baskin, 1998; Nikolaeva, 1977). Those with horticultural interest include simple and epicotyl types.

Seeds with simple morphophysiological dormancy usually require warm $\left(>15^{\circ} \mathrm{C}\right)$ followed by cold $\left(1\right.$ to $\left.10^{\circ} \mathrm{C}\right)$ conditions during which time the embryo develops during the warm temperature cycle and then breaks physiological dormancy during the chilling cycle. Various temperate zone herbaceous and woody plants fall into this category, including windflower (Anemone), twinleaf (Jeffersonia), ash (Fraxinus), yew (Taxus), and holly (Ilex) (Nikolaeva, 1977). In nature, these seeds are usually shed from the plant with an undeveloped (linear) embryo that requires a warm period to initiate growth inside the seed coverings. Once the embryo reaches a certain size, it can respond to chilling temperature, which releases the seed from physiological dormancy.

In some species, cultivated and wild forms differ with respect to morphophysiological dormancy. For example, in Anemone coronaria L, cultivated 'de Caen' seeds showed only morphological dormancy (requiring only warm treatment), while wild populations of Anemone displayed morphophysiological dormancy and required warm followed by cold stratification (Horovitz et al., 1975).

An interesting species with morphophysiological dormancy is North American pawpaw [Asimina triloba (L.) Dunal.] (Finneseth et al., 1998). This species requires $\approx 8$ weeks of chilling temperatures to relieve endogenous physiological dormancy followed by warm temperatures to satisfy morphological dormancy prior to germination. This sequence is a reversal of the more common warm followed by cold temperature to relieve morphophysiological dormancy.

Seeds with epicotyl dormancy display the most fascinating dormancy patterns found in seeds. These seeds have separate dormancy conditions for the radicle and epicotyl (Barton, 1944; Baskin and Baskin, 1998; Crocker, 1948). These species fall into two subgroups. In one group, seeds initially germinate during a warm period of 1 to 3 months to produce root and hypocotyl growth beyond the seed coverings, but then require 1 to 3 months of subsequent chilling to enable the epicotyl to grow (simple epicotyl dormancy). This group includes various species of lily (Lilium), viburnum, peony (Paeonia), as well as black cohosh [Cimicifugaracemosa (L.) Nutt.] and liverwort (Hepatica acutiloba DC.). The response of the epicotyl to chilling varies with the size of the radicle (Barton and Chandler, 1957). For peony, $85 \%$ of the epicotyls exposed to 7 weeks of chilling grew if the radicle had reached $4 \mathrm{~cm}$ in length. In contrast, only $40 \%$ of the epicotyls were released from dormancy under the same conditions with smaller $2-3 \mathrm{~cm}$ radicles.

In the second group, both the epicotyl and the radicle require chilling, but are released from dormancy at different times. Seeds in this group require a chilling period to relieve radicle dormancy, followed by a warm period to allow the radicle to grow, then a second cold period to release the epicotyl from dormancy. In nature, such seeds require at least two full growing seasons to complete germination. These are the seeds for which the term "double dormancy" was first coined. Examples include bloodroot (Sanguinaria canadensis L.), Trillium sp., and lily-of-the-valley (Convallaria majalis L.). There are also seed population differences in this group. Barton (1944) showed that in both bloodroot and Solomon's seal (Polygonatum multiflorum L.) about half the seeds showed simple epicotyl dormancy while the other half showed double dormancy.

\section{Secondary dormancy}

Under natural conditions, seeds released from primary dormancy often experience secondary dormancy when environmental conditions are not favorable for germination (Bewley and Black, 1994; Crocker, 1916; Karssen et al., 1983; Khan, 1981). These conditions can include unfavorable temperature, prolonged light or darkness, water stress, and anoxia. These conditions are particularly involved in the seasonal rhythms (dormancy cycling) and prolonged survival of weed seeds in soil (Baskin and Baskin, 1998; Egley, 1995).

Chilling temperatures can induce secondary dormancy in nondormant seeds. Coreopsis lanceolata $\mathrm{L}$. seeds were relieved of nondeep physiological dormancy by dry storage for 6 to 18 months. The stored seeds germinated at high percentages at 15 and $25^{\circ} \mathrm{C}$, but entered secondary dormancy if held at $5^{\circ} \mathrm{C}$ (Banovetz and Scheiner, 1994).

In some cases, seeds that did not require chilling stratification to satisfy primary dormancy may require it for release from secondary dormancy. For example, Nemophila insignis Doug. Ex Benth. seeds require darkness to germinate. If these seeds are exposed to light for a period of time, they enter secondary dormancy and will no longer germinate in the dark without a chilling treatment (Chen, 1968). 


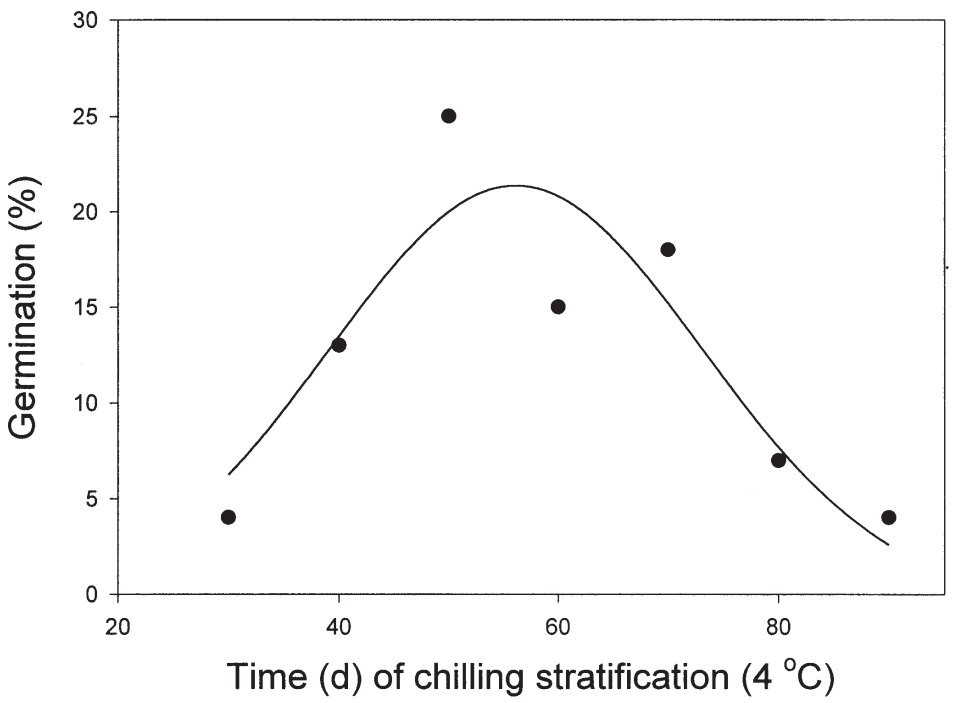

Fig. 2. Percentage of peach seeds that germinate at $20^{\circ} \mathrm{C}$ as a function of time under chilling stratification at $4{ }^{\circ} \mathrm{C}$. (redrawn from data in Seeley and Damavandy, 1985).

A high-temperature environment for germination can induce a common form of secondary dormancy termed thermodormancy. Thermodormancy can develop in species such as apple (Malus), lettuce (Lactuca), celery (Apium), Schizanthus, and pansy (Viola) if the germination temperature is too high $\left(>25^{\circ} \mathrm{C}\right)$. This phenomenon should not be confused with the thermal inhibition most seeds experience when the temperature exceeds the maximum temperature for germination. Seeds experiencing thermodormancy will not germinate when the temperature returns to near optimum temperatures, while thermally inhibited seeds will germinate when temperatures are lowered.

Seeds of some species of ash (Fraxinus) display morphophysiological dormancy that requires extended time (10 to 18 weeks) of warm stratification followed by additional time at $5{ }^{\circ} \mathrm{C}(\approx 12$ weeks $)$ to relieve primary dormancy (Young and Young, 1992). Stratified seeds showed considerable secondary dormancy when germinated at constant $20^{\circ} \mathrm{C}$ or alternating $20 / 30^{\circ} \mathrm{C}$ (Piotto, 1994). Interestingly, there was no secondary dormancy seen in a widely fluctuating $25 / 5{ }^{\circ} \mathrm{C}$ germination environment. This and other studies suggest that caution should be taken when interpreting laboratory experiments where germination temperatures are held constant or day/night temperature fluctuations are minimized compared to the outside environment (Baskin and Baskin, 1998; Hilhorst, 1998).

Apple seeds require chilling stratification to relieve primary endogenous dormancy. Following release from dormancy, they are sensitive to induction into secondary dormancy at germination temperatures above $30^{\circ} \mathrm{C}$ (Visser, 1954). Ozga and Dennis (1991) determined that abscisic acid content was not well correlated with induction of secondary dormancy. Hillhorst (1998) presents a convincing case for considering temperature-associated changes in membranes being responsible for release from dormancy, especially in seeds displaying secondary dormancy. Membranes adjust to varying temperature to maintain their fluid- ity, which directly impacts integral membrane proteins. These changes in the membrane may be related to release from primary dormancy or induction into secondary dormancy.

\section{Germination models}

A number of attempts have been made to develop mathematical models that predict seedling emergence from dormant seeds (Bradford 1996; Christensen et al., 1996; Forcella, 1998; Kebreab and Murdoch, 1999; Pritchard et al., 1996; Seeley and Damavandy, 1995). Some models that consider only temperature effects on dormancy release have been remarkably effective. For example, Bauwmeester and Karssen (1992) were able to predict seedling emergence in the field for a number of weed species using a "germination temperature window" based on the previous exposure of these seeds to various temperatures. Although temperature is implicated in most aspects of seed dormancy release, it is apparent that additional features such as population effects, seed moisture, light, and nitrate levels must be considered when developing an effective model for dormancy release under field conditions (Hilhorst, 1998).

Genetic and environmental (primarily temperature) factors affect seed dormancy release. The genetic component can influence entire populations of seeds or individual seeds within a seed lot. An example where entire populations of seeds show different depths of dormancy is illustrated in Prunus serotina J.G. Ehrh. seeds collected from different climactic zones (Farmer and Barnett, 1972). Seeds from ecotypes collected from higher altitudes required longer periods of chilling stratification to relieve dormancy and were slower to germinate at permissive germination temperatures following stratification compared to seeds collected from lower altitudes.

Genotype differences need to be considered when applying models that may have been generated using only one ecotype. Perez (1997) compared stratification requirements between low bud chilling peach accessions from subtropical regions with those of high-chilling accessions. Low-chilling genotypes showed dormancy release at temperatures as high as 14 ${ }^{\circ} \mathrm{C}$, whereas this temperature had no impact on germination in high-chilling genotypes.

There are also differences in the depth of dormancy observed for seeds within a seed lot. The complexity of this genetic component becomes apparent when considering the correlation between seed-chilling requirements and bud-chilling requirements of plants (Powell, 1987). In studies with almond (Prunus dulcis L.), a high quantitative correlation was observed between the mean time for bud and seed dormancy release in seedling populations and the mean for both the seed and pollen parents (Kester, 1969). However, there was a low correlation between the time required to release dormancy in each individual seed and the subsequent chilling requirements for buds of the new plant developing from that embryo (Kester et al., 1977). This difference suggests that dormancy involves both a genetic component within the embryo and a maternal component from the seed parent. As a result, a great deal of variability can exist in the time to dormancy release in individual seeds within a given seed lot and between different seed lots of the same species collected in different years and different locations.

This maternal vs. paternal inheritance factor can be illustrated in reciprocal crosses of petunia (Girard, 1990). Seed coverings (maternal tissue) have an important influence on dormancy release (Hartmann et al., 2002) and these tissues are ostensibly maternal tissue. In petunia (Petunia $\times$ hybrida Hort. Vilm.-Andr.), the requirement for light was maternally inherited, while endogenous dormancy within the embryo was under paternal control.

Whether controlled by environmental factors during development or by genetic factors within the embryo or seed coverings, the time required for dormancy release in individual seeds within a given seed lot is about normally distributed (Fig. 2). This suggests that release from seed dormancy could be described using a population-based thermal time model similar to well-characterized thermal time models for germination in nondormant seeds (Bradford, 1996). Accordingly, Pritchard et al. (1996) used thermal time to describe dormancy loss in horsechestnut (Aesculus hippocastanum L.) seeds. A negative linear relationship was observed between dormancy release with chilling over a range of stratification temperatures.

A second factor affecting predictive models for seed dormancy release is the interaction between temperature and seed moisture content. Chilling stratification is not effective unless seeds are hydrated. In nature, the degree of seed hydration varies depending on the environment. Therefore, there is a critical moisture content below which seeds would not be positively affected by chilling for dormancy release. In several conifer species, the critical moisture content appears to be $\approx 25 \%$ moisture on a fresh weight basis (Gosling and Rigg, 1990). About 33\% seed moisture allows dormancy release to proceed without 
allowing germination during prolonged storage (Jones and Gosling, 1994). Downie et al. (1998) also observed that dormancy release in spruce [Picea glauca (Moench.) Voss.] seeds was achieved at a moisture content starting at $\approx 25 \%$. At this moisture content, seeds were at the boundary between water binding regions 3 and 4 as determined by moisture sorption isotherms (Vertucci and Farrant, 1995). In this condition, cellular components are hydrated, but not sufficiently to support turgor-driven cell expansion. Based on cellular properties in these moisture ranges, they suggested that protein hydration and possibly synthesis was required for release from dormancy in seeds requiring chilling stratification (Downie et al., 1998). Interestingly, freshly harvested seeds that require after-ripening (nondeep physiological dormancy) are released from dormancy in water binding region 2 (for example, wild oats, Foley, 1994). This example indicates that the internal processes responsible for dormancy release are probably different for seeds with endogenous physiological dormancy that experience dormancy loss due to dry storage compared to those requiring chilling stratification.

Finally, the most interesting problem with models that attempt to describe the time required for dormancy release at a given temperature is conditional dormancy. This problem goes directly to the question "what constitutes dormancy release?". Dormancy cycling, as observed in many species, is a function of conditional dormancy (Baskin and Baskin, 1998). It is a transitional state between the dormant and nondormant seed condition. This transition can be observed by evaluating germination over a range of germination temperatures. Nondormant seeds germinate rapidly over a wide range of temperatures, while conditionally dormant seeds germinate only within restrictive (optimum) temperatures (Vegis, 1964). In most laboratory studies, seeds are exposed to a dormancy releasing treatment (e.g., chilling temperatures) and the time to dormancy loss as indicated by germination at an optimal temperature is recorded. In reality, this measurement is an indication of the time required to move from a dormant to conditionally dormant state. The time required to achieve a fully nondormant state would be indicated by the ability to germinate over a range of temperatures (Baskin and Baskin, 1998). In nature, seeds can go through years of dormancy cycling, each cycle containing periods of dormancy, nondormancy and conditional dormancy. When other factors (such as light) are not limiting, germination occurs only when the degree of dormancy release corresponds to an appropriate germination temperature range. Therefore, models that attempt to predict germination in dormant seeds in nature must consider the impact of temperature on the degree of dormancy release (conditional dormancy) and adjust the model to account for corresponding permissive germination temperatures.

\section{Literature Cited}

Association of Official Seed Analysts. 1993 Rules for testing seeds. J. Seed Technol. $16: 1-113$

Atwater, B.R. 1980. Germination, dormancy and morphology of the seeds of herbaceous ornamental plants. Seed Sci. Technol. 8:523-573.

Banovetz, S.J. and S.M. Scheiner. 1994. Secondary seed dormancy in Coreopsis lanceolata. Amer. Mid. Nat. 131:75-83.

Barton, L.V. 1944. Some seeds showing special dormancy. Contrib. Boyce Thomp. Inst. 13: 259-271.

Barton, L.V. and C. Chandler. 1957. Physiological and morphological effects of gibberellic acid on epicotyl dormancy of tree peony. Contrib. Boyce Thomp. Inst. 19:201-214.

Baskin,C.C. and J.M. Baskin. 1998. Seeds. Ecology, biogeography, and evolution of dormancy and germination. Academic, New York.

Baskin, J.M., C.C. Baskin, and X. Li. 2000. Taxonomy, anatomy and evolution of physical dormancy in seeds. Plant Species Biol. 15: 139-152.

Bauwmeester, H.J. and C.M. Karssen. 1992. The dual role of temperature in the regulation of the seasonal changes in dormancy and germination of seeds of Polygonum persicaria L. Oecologia 90: 88-94.

Bewley, J.D. and M. Black. 1994. Seeds: Physiology of development and germination. Plenum Press, New York.

Bradford, K.J. 1996. Population-based models describing seed dormancy behaviour: Implications for experimental design and interpretation, $\mathrm{p}$. 313-339. In: G.A. Lang (ed.). Plant dormancy: Physiology, biochemistry, and molecularbiology. CAB Intl., Wallingford, U.K.

Casal, J.J. and R.A. Sánchez. 1998. Phytochromes and seed germination. Seed Sci. Res. 8 : 317-329.

Chen, S.S.C. 1968. Germination of light-inhibited seed of Nemophila insignis. Amer. J. Bot. 55: 1177-1183.

Christensen, M., S.E. Meyer, and P.S. Allen. 1996 A hydrothermal time model of seed after-ripening in Bromus tectorum L. Seed Sci. Res. 6: 1555-163.

Crocker, W. 1916. Mechanics of dormancy in seeds. Amer. J. Bot. 3:99-120

Crocker, W. 1948. Growth of plants. Reinhold, New York.

Downie, B., J. Coleman, G. Scheer, B.S.P. Wang, M. Jensen, and N. Dhir. 1998. Alleviation of seed dormancy in white spruce (Picea glauca $[\mathrm{Mo}-$ ench.] Voss.) is dependent on the degree of seed hydration. Seed Sci. Technol. 26:555-569.

Ecker, R., A. Barzilay, and E. Osherenko. 1994. The genetic relations between length of time to germination and seed dormancy in lisianthus (Eustoma grandiflorum). Euphytica 80:125-128.

Egley, G.H. 1989. Water-impermeable seed coverings as barriers to germination, p. 207-224. In: R.B. Taylorson (ed.). Recent advances in the development and germination of seeds. Plenum Press, New York.

Egley, G.H. 1995. Seed germination in soil: Dormancy cycles, p. 529-543. In: J. Kigel, and J. Galili (eds.). Seed development and germination. Marcel Dekker, New York.

Evenari, M. 1981. The history of germination research and the lesson it contains for today. Israel J. Bot. 29:4-21.

Farmer,R.E. and P.E. Barnett. 1972. Altitudinal variation in seed characteristics of black cherry in the southern Appalachians. For. Sci. 18:169-175.

Finneseth, C.H., D.R. Layne, and R.L. Geneve. 1998. Requirements for seed germination in North American pawpaw [Asimina triloba (L.) Dunal]. Seed Sci. Technol. 26:471-480.

Flemion, F. and E. Waterbury. 1945. Further studies with dwarf seedlings of non-after-ripened peach seeds. Contrib. Boyce Thomp. Inst. 13: 415-422.

Foley, M. 1994. Temperature and water status of seed affect afterripening in wild oat (Avena fatua). Weed Sci. 42:200-204.

Forcella, F. 1998. Real-time assessment of seed dormancy and seedling growth for weed management. Seed Sci. Res. 8:201-209.

Geneve, R.L. 1998. Seed dormancy in commercial vegetable and flower seeds. Seed Technol. 20: 236-250.

Girard, J. 1990. Study of the inheritance of seed primary dormancy and the ability to enter secondary dormancy in Petunia: Influence of temperature, light and gibberellic acid on dormancy. Plant Cell Environ. 13:827-832.

Gosling, P.G. and P. Rigg. 1990. The effect of moisture content and prechilling duration on the efficiency of dormancy breakage in Sitka spruce (Picea sitchensis) seed. Seed Sci. Technol. 18:337-343.

Hadnagy, A. 1972. Lettuce seed dormancy. Proc. Intl. Seed Test. Assn. 37:865-880

Hartmann, H.T, D.E. Kester, F.T. Davies, Jr., and R.L. Geneve. 2002. Hartmann and Kester's plant propagation: Principles and practices. 7th ed. Prentice Hall, New Jersey.

Hilhorst, H.W.M. 1998. The regulation of secondary dormancy. The membrane hypothesis revisited. Seed Sci. Res. 8:77-90.

Horovitz, A., S. Bullowa, and M. Negbi. 1975. Germination characteristics in wild and cultivated anemone. Euphytica 24:213-220.

Jones, S.K. and P.G. Gosling. 1994. 'Target moisture content' prechill overcomes the dormancy of temperate conifer seeds. New For. 8:309-321.

Karssen, C.M., D.L.C. Brinkhorst-van der Swan, A.E. Breekland, and M. Koornneef. 1983. Induction of dormancy during seed development by endogenous abscisic acid deficient genotypes of Arabidopsis thaliana (L.) Heynh. Planta 157: $158-165$.

Kebreab, E., and A.J. Murdoch. 1999. A model of the effects of a wide range of constant and alternating temperatures on seed germination of four Orobanche species. Ann. Bot. 84:549-557.

Kester, D.E. 1969. Pollen effects on chilling requirements of almond and almond hybrid seeds. J. Amer. Soc. Hort. Sci. 94:318-321.

Kester, D.E., P. Raddi, and R. Asay. 1977. Correlations of chilling requirements for germination, blooming and leafing within and among seedling populations of almond. J. Amer. Soc. Hort. Sci. 102:145-148.

Khan, A.A. 1981. Hormonal regulation of primary and secondary dormancy. Israel J. Bot. 29: 207-224.

Lang, G.A. 1987. Dormancy: A new universal terminology. HortScience 22:817-820.

Manning, J.C. and J. van Staden. 1987. The role of the lens in seed imbibition and seedling vigour of Sesbania punicea (Cav.) Benth. (Leguminosae, Papilinoideae). Ann. Bot. 59:705-713.

Montero, F., J. Herrera, and R. Alizaga. 1990. Effect of gibberellic acid and prechilling on dormancy breaking in snapdragon (Antirrhinum majus) seeds. Agronomia Costarricense 14:55-60.

Morrison, D.A., D.A. McClay, C. Porter, and S Rish. 1998. The role of the lens in control- 
ling heat-induced breakdown of testa-imposed dormancy in native Australian legumes. Ann. Bot. 82:35-40.

Nagao, M.A., K. Kanegawa, and W.S. Sakai. 1980. Accelerating palm seed germination with gibberellic acid, scarification, and bottom heat. HortScience 15:200-201.

Nikolaeva, M.G. 1977. Factors affecting the seed dormancy pattern, p. 51-76. In: A.A. Khan (ed.). The physiology and biochemistry of seed dormancy and germination. North-Holland Publishing, Amsterdam.

Ozga, A. and F.G. Dennis, Jr. 1991. The role of abscisic acid in heat stress-induced secondary dormancy in apple seeds. HortScience 26: 175-177.

Perez-G, S. 1997. Genotypic differentiation in temperature requirements for stratification in subtropical peach seeds. HortScience 32: 1064-1068.

Piotto, B. 1994. Effects of temperature on germination of stratified seeds of three ash species. Seed Sci. Technol. 22:519-529.

Powell, L.E. 1987. Hormonal aspects of bud and seed dormancy in temperate-zone woody plants. HortScience 22:845-850.

Pritchard, H.W., K.J. Steadman, J.V. Nash, and C. Jones. 1996. Development of a thermal time model for the quantification of dormancy loss in Aesculus hippocastanum seeds. Seed Sci. Res. 6:127-135.

Quinlivan, B.J. 1968. The softening of hard seeds of sand-plain lupin (Lupinus varius L.). Austral. J. Agr. Res. 19:507-515.

Roberts, E.H. 1965. Dormancy in rice seed. IV. Varietal responses to storage and germination temperatures. J. Expt. Bot. 16:341-349.

Seeley, S.D. 1997. Quantification of endodormancy in seeds of woody plants. HortScience 32:615-617.

Seeley, S.D. and H. Damavandy. 1985. Response of seed of seven deciduous fruits to stratification temperatures and implications for modeling. J. Amer. Soc. Hort. Sci. 110:726-729.

Simmonds, J. 1980. Increasing seedling establishment of Impatiens wallerana in response to low temperature or polyethylene glycol seed treatments. Can. J. Plant Sci. 60:561-569.
Vanhatalo, V., K. Leinonen, H. Rita, and M. Nygren. 1996. Effect of prechilling on the dormancy of Betula pendula seeds. Can. J. Res 26:1203-1208.

Vegis, A. 1964. Dormancy in higher plants. Annu. Rev. Plant Physiol. 15:185-224.

Vertucci, C.W. and J.M. Farrant. 1995. Acquisition and loss of desiccation tolerance, p. 237-272. In: J. Kigel and G. Galili (eds.). Seed development and germination. Marcell Dekker, New York.

Visser, T. 1954. After-ripening and germination of apple seeds in relation to the seedcoats. Proc. Koninklijke Nederlandse Akademie van Wetenschappen C57:175-185.

Wartidininghsih, N. and R.L. Geneve. 1994. Osmotic priming or chilling stratification improve seed germination of purple coneflower (Echinacea purpurea). HortScience 29:1445-1448.

Weston, L.A., R.L. Geneve, and J.E. Staub. 1992. Seed dormancy in Cucumis sativus var. hardwickii (Royle) Alef. Scientia Hort. 50:35-46.

Young, J.A. and C.G. Young. 1992. Seeds of woody plants in North America. Revised ed. Dioscorides Press, Portland. 